\title{
PENINGKATAN KEMAMPUAN BERPIKIR KREATIF MATEMATIS SISWA MELALUI MODEL PEMBELAJARAN MISSOURI MATHEMATICS PROJECT (MMP)
}

\author{
NOVI MARLIANI \\ marliani_novi@yahoo.com \\ Program Studi Pendidikan Matematika, Fakultas Teknik, Matematika, dan IPA \\ Universitas Indraprasta PGRI
}

\begin{abstract}
Abstrak. Penelitian ini merupakan penelitian yang berupa studi pustaka dan bertujuan untuk melihat kemampuan berfikir kreatif matematis siswa melalui pembelajaran dengan model Missouri Mathematics Project (MMP). Dalam mempelajari matematika, berpikir menjadi pokok penting. Pelajaran matematika mengharuskan setiap siswa memiliki kemampuan memahami rumus, berhitung, menganalisis, mengelompokkan objek, membuat alat peraga, membuat model matematika, dan lain-lain. Kegiatan tersebut tidak hanya memerlukan kegiatan berpikir biasa (konvergen), tetapi dibutuhkan kemampuan berpikir tinggi (divergen). Kenyataannya banyak sekolah yang mempunyasiswa dengan kemampuan berpikir masih terbilang rendah. Kemampuan berpikir kreatif matematis dapat diartikan sebagai kemampuan menyelesaikan masalah matematika dengan lebih dari satu penyelesaian dan siswa berpikir lancar, luwes, melakukan elaborasi, dan memiliki orisinalitas dalam jawabannya. Berpikir kreatif matematis dapat bermanfaat untuk melatih kemampuan berpikir divergen pada matematika. Oleh karena itu, untuk mewujudkannya diperlukan pemilihan model pembelajaran yang tepat dan efektif. Salah satu model pembelajaran matematika yang dapat digunakan untuk melatih dan meningkatkan kemampuan berpikir kreatif matematis siswa adalah model pembelajaran Missouri Mathematics Project (MMP).
\end{abstract}

Kata Kunci: kemampuan berfikir kreatif matematis, model pembelajaran missouri mathematics project (MMP).

Abstract. This research study in the form of literature and aims to look atcreative thinking skills of students through learning mathematical model of Missouri Mathematics Project(MMP). In studying mathematics, think are of central importance. Mathrequires that every student has the ability to understand the formula, calculate, analyze, categorize objects, making props, create mathematical models, and others. These activities not only require regular thinking activities (convergent), but it takes the ability to think high (divergent). In fact many schools with the ability to thinkis still fairly low. Creative thinking skills can be defined mathematically as theability to solve mathematical problems with more than ones ettlement and students thinks mooth, supple, elaborating, and have originality in the answer. Creative thinking can be beneficial to train mathematical divergent thinking skills in mathematics. There fore, it is necessary to realize the selection of appropriate learning models and effective. One of mathematical learning model that can be used to train and improve students' ability to think creatively is mathematical learning model Missouri Mathematics Project (MMP).

Keywords : mathematical creative thinking ability, learning models missouri mathematics project (MMP). 


\section{PENDAHULUAN}

Pendidikan merupakan unsur yang penting dalam rangka mendukung pembangunan nasional melalui pendudukan sumber daya manusia yang unggul. Hal ini sesuai dengan pendidikan nasional dalam UU nomor 20 tahun 2003 pada Bab II pasal 3 yaitu Pendidikan nasional berfungsi mengembangkan kemampuan dan membentuk watak serta peradaban bangsa yang bermanfaat dalam rangka mencerdaskan kehidupan bangsa, bertujuan untuk berkembangnya potensi peserta didik agar menjadi manusia yang beriman dan bertakwa kepada Tuhan Yang Maha Esa, berakhlak mulia, sehat, berilmu, cakap, kreatif, mandiri, dan menjadi warga negara yang demokratis serta bertangggung jawab.Oleh karena itu, pendidikan perlu dilaksanakan terpadu, serasi dan teratur serta pelaksanaan pendidikan didukung oleh partisipasi aktif pemerintah, berbagai kelompok masyarakat, pihak orang tua atau dewan kependidikan.

Di era yang serba modern dan canggih,dewasa ini sangat menuntut adanya sumber daya manusia (SDM) yangberkualitas dalam segala aspek. SDM yangberkualitas merupakan suatu keniscayaan yangtidak bisa ditawar-tawar lagi. Menurut Darmadi (2010:235)Untuk memajukanIPTEK ini pun diperlukan adanya pemahamantentang ilmu matematika yang kuat sejak dini. Mengingat akanpentingnya ilmu matematika bagiperkembangan dunia maka sangatlahmemprihatinkan jika kita melihat kondisisiswa yang kurang begitu menguasaiilmu matematika. Realita ini terlihat dari datahasil penilaian yang dilakukan pada tahun 2012 oleh Organization Econimic Cooperation and Development (OECD) yang bernama Program for International Student Assesment (PISA) mendapatkan hasil bahwa Indonesia berada di peringkat 64 dari 65 negara (Kompas, 5 Desember 2013). Hal ini tentunyamenjadi perhatian bagi kita semua sudah sejauh mana keefektifan pendidikan di Indonesia.

Dalam mempelajari matematika, berpikir menjadi pokok penting. Pelajaran matematika mengharuskan setiap siswa memiliki kemampuan memahami rumus, berhitung, menganalisis, mengelompokkan objek, membuat alat peraga, membuat model matematika, dan lain-lain. Kegiatan tersebut tidak hanya memerlukan kegiatan berpikir biasa (konvergen), tetapi dibutuhkan kemampuan berpikir tinggi (divergen). Kenyataannya banyak sekolah-sekolah yang mempunyai kemampuan berpikir siswa masih terbilang rendah. Sebagai contoh siswa merasa kebingungan untuk melakukan pengelompokan unsur yang diketahui dalam soal, langkah awal pengerjaan soal, kesalahan dalam melakukan operasi matematika, dan monoton terhadap contoh soal yang diberikan oleh gurunya.

Mengingat matematika sebagai induk dari ilmu pengetahuan maka matematika berperan penting baik sebagai alat bantu, ilmu, pembimbing pola pikir maupun pembentuk sikap, oleh sebab itu proses pembelajaran matematika harus dapat dilakukan dengan baik. Hal ini sesuai dengan pernyataan Handoko (2013:189) yang menyatakan bahwa "matematika dapat difungsikan untuk mengembangkan kemampuan berpikir yang sistematis, logis, kreatif, disiplin, dan kerjasama yang efektif dalam kehidupan yang modern dan kompetitif". Hal ini mengharuskan guru agar dapat menciptakan pembelajaran matematika yang efektif dan efisien dengan strategi dan pemilihan model pembelajaran yang tepat.

Menurut pernyataan Handoko di atas dapat disimpulkan bahwa fungsi dari belajar matematika salah satunya adalah mengembangkan kemampuan berpikir kreatif. Kemampuan berpikir kreatif dalam hubungannya dengan matematika lebih tepatnya disebut kemampuan berpikir kreatif.

Kemampuan berpikir kreatif matematis dapat diartikan sebagai kemampuan menyelesaikan masalah matematika dengan lebih dari satu penyelesaian dan siswa berpikir lancar, luwes, melakukan elaborasi, dan memiliki orisinalitas dalam jawabannya. 
Berpikir kreatif matematis dapat bermanfaat untuk melatih kemampuan berpikir divergen pada matematika. Oleh karena itu, untuk mewujudkannya diperlukan pemilihan model pembelajaran yang tepat dan efektif.

Salah satu model pembelajaran matematika yang dapat digunakan untuk melatih dan meningkatkan kemampuan berpikir kreatif matematis siswa adalah model pembelajaran Missouri Mathematics Project (MMP). Menurut Agoestanto dan Savitri (2013:72) menyatakan bahwa "model pembelajaran Missouri Mathematics Project (MMP) menuntut keaktifan siswa dalam pembelajaran karena guru hanya sebagai fasilitator yang mendampingi dan hanya membantu siswa menemukan pengetahuannya". Model pembelajaran Missouri Mathematics Project (MMP) melatih siswa menjadi mandiri, kerjasama, dan berpikir kreatif dalam menyelesaikan permasalahan matematka.

Model pembelajaran Missouri Mathematics Project (MMP) memiliki langkahlangkah dalam pelaksanaannya yaitu, review, pengembangan, kerja kelompok/kooperatif, seatwork, dan homework. Karakteristik dari model pembelajaran Missouri Mathematics Project (MMP) adalah adanya lembar tugas proyek (lembar kerja siswa), dimana dengan adanya tugas proyek tersebut diharapkan mampu dapat meningkatkan hasil belajar matematika dan kemampuan berpikir kreatif siswa yang dapat dilakukan dengan cara menyelesaikan proyek tersebut secara individu maupun kelompok. Menurut Jannah, dkk. (2013:63), "model pembelajaran Missouri Mathematics Project (MMP) melatih kerjasama antar siswa pada langkah kerja kooperatif, mengerjakan lembar kerja secara berkelompok akan membuat siswa saling membantu kesulitan masing-masing dan saling bertukar pikiran.

Dalam model pembelajaran MMP, siswa tidak hanya belajar di dalam kelas saja karena siswa diberikan pekerjaan rumah sehingga siswa mempunyai waktu belajar yang lebih banyak. Tugas-tugas yang telah dikerjakan oleh siswa akan dibahas bersama-sama sehingga siswa akan mengetahui apakah jawaban yang didapatnya benar atau salah.

Berdasarkan uraian di atas maka saya mencoba untuk memberikan paparang tentang Kemampuan Berpikir Kreatif Matematis Siswa Melalui Pembelajaran ModelMissouri Mathematics Project (MMP).

\section{PEMBAHASAN}

\section{Kemampuan Berpikir Kreatif Matematis}

Kehidupan manusia tidak lepas dari kegiatan berpikir. Salah satu contoh kegiatan berpikir adalah pada saat individu berusaha mencari cara dalam memecahkan suatu permasalahan dalam kehidupan. Dalam hal contoh kecil, ketika kita ingin pulang dari aktivitas bekerja pada saat kondisi jalan yang macet terpikirkan dibenak kita untuk mencari jalan yang lebih lancar atau tingkat kemacetannya lebih rebih. Berpikir merupakan suatu kegiatan mental yang melibatkan kinerja otak terhadap suatu informasi yang dapat menimbulkan berkembangya ide ataupun konsep.

De Bono (2007:24) mendefinisikan berpikir sebagai keterampilan mental yang memadukan kecerdasan dengan pengalaman.Menurut pendapat tersebut dapat disimpulkan bahwa kecerdasan dengan pengalaman memiliki kaitan dalam kemampuan berpikir, ibarat mobil dengan pengendaranya. Pengendara yang memiliki kemampuan dan pengalaman dalam mengemudi tentunya akan mengendarai mobilnya dengan hati-hati, mematuhi rambu lalu lintas, dan tidak mengabaikan keselamatan pejalan kaki. Begitu pula dengan pengalaman akan membuat pemikir menjadi cerdas memutuskan suatu langkah yang diambil dalam menyelasaikan masalah.Menurut psikologi Gestalf dalam Nasution (2013:107) bahwa berpikir merupakan keaktifan psikis yang abstrak yang prosesnya tidak dapat kita amati dengan alat indera kita. Menurut pendapat diatas dapat disimpulkan bahwa aktifitas berpikir seseorang tidak dapat di amati oleh indra kita, 
seperti halnya seseorang yang sedang diam belum tentu ia sedang berpikir karena dalam aktivitas berpikirnya tidak dapat diamat. Pendapat yang senada diutarakan oleh Purwanto (2002:43) yang menyebutkan bahwa berpikir adalah suatu keaktifan manusia yang mengakibatkan penemuan yang terarah kepada suatu tujuan. Menurut pendapat di atas buah dari berpikir adalah mendapatkan suatu ide atau penemuan yang dapat digunakan untuk tujuan tertentu. Menurut Nasution (2013:108), Berpikir divergen penting untuk mencermati permasalahan matematika dari segala perspektif dan mengkonstruksikan segala kemungkinan pemecahannya. Maka kemampuan berpikir divergen melatih siswa berpikir kreatif dengan menemukan berbagai macam solusi masalah. Berpikir divergen sangat tepat dilatih pada pelajaran matematika karena dalam matematika meyelesaikan suatu soal tidak hanya monoton satu cara penyelasaian, tetapi banyak cara. Jadi berpikir adalah kemampuan mental dalam menggabungkan dan mengorganisasikan antara kecerdasan dan pengalaman yang digunakan untuk mengembangkan kemampuan berpikir dan menyelesaikan suatu permasalahan. Setiap manusia dalam hidupnya pasti melakukan kegiatan berpikir dengan kadar kecerdasan, usia, dan kondisi yang dialami.

Kreatif berasal dari bahasa Inggris 'create' yang artinya menciptakan, sedangkan kreatif mengandung pengertian memiliki daya cipta, mampu merealisasikan ide-ide dan perasaannya sehingga tercipta sebuah komposisi dengan warna dan nuansa baru. Orang kreatif lebih fleksibel dibandingkan orang yang kurang kreatif. Keflesibelan ini membuat orang kreatif dapat menghindari rintangan-rintangan dalam menghadapi persoalan yang dihadapi. Kreativitas sering dikatakan sebagai suatu produk kreatif. Dihasilkannya suatu produk kreatif, apapun jenisnya, pasti didahului oleh pembentukan ide kreatif. Ide kreatif dihasilkan melalui proses berpikir yang melibatkan aktifitas kognitif. Menurut pendapat di atas, kecerdasan seeorang berpengaruh terhadap ide-ide kreatif yang dihasilkan dengan kata berarti ide kreatif bergantung pada kecerdasan. Dalam kemampuan seseorang untuk dapat berhasil dalam kehidupannya antara lain ditentukan oleh keterampilan berpikirnya, terutaman dalam upaya memecahkan masalahmasalah kehidupan yang dihadapinya. Menurut pendapat di atas dapat disimpulkan bahwa berpikir akan memberikan solusi dari permasalah yang dihadapi oleh seseorang. Dalam proses pembelajaran matematika, siswa pasti melakukan aktivitas berpikir untuk menyerap informasi yang diberikan oleh guru, memahami konsep matematika maupun untuk menyelesaikan suatu permasalahan matematika itu sendiri. Siswa dalam melaksanakan aktivitas pembelajaran rutin matematika seperti mengerjakan tugas rumah, menghafal rumus, dan pengulangan contoh-contoh hanya memberikan latihan pada kemampuan berpikir konvergennya. Padahal untuk dapat berpikir tingkat tinggi dalam belajar matematika diperlukan kemampuan berpikir divergen.

Malaka (2011:67) mengemukakan bahwa jangan berpikir bahwa kreatif itu hanya membuat hal-hal yang baru, hal tersebut salah karena manusia tidak pernah membuat hal baru. Manusia hanya bias menemukan apa yang belum ditemukan oleh orang lain, manusia hanya bias mengubah atau menggabungkan hal-hal yang sudah ada, sekali lagi bukan menciptakan hal yang baru. Maka kreatif hanya melanjutkan hal yang sudah ada bukan menciptakan atau membuat hal yang benar-benar baru, tetapi sifatnya yang lebih baru dan lebih unggul. Definisi lain mengenai kreatif adalah orang kreatif akan mencarihal-hal yang baru, menemukan dan mengembangkan hal yang baru (Johnson, 2013:29). Seseorang yang biasa dalam hidupnya berpikir kreatif akan berdampak pada kepribadiaan yang kreatif. Hal ini akan membentuk pribadi yang kreatif biasanya lebih terorganisir dalam tindakan, rencana inovatif serta produk orisinil mereka telah diperkirakan dengan matang lebih dahulu dengan mempertimbangkan masalah yang mungkin timbul dengan implikasinya. Maka kreatif adalah merancang hal baru dan 
orisinil dengan matang beserta hal positif dan negatif yang mungkin timbul dalam pelaksaannya.

Kata kreatif dengan kata kreativitas tidak dapat dipisahkan. Kata kreatif membentuk kata kreativitas yang memiliki arti menciptakan hal-hal baru dengan atau tanpa mengkombinasikan sesuatu yang sudah ada. Kreativitas dapat juga dikatakan dari proses berpikir kreatif, dimana kreativitas adalah produknya.Kreativitas dalam proses pembelajaran sangat di butuhkan terlebih dalam mata pelajaran matematika. Kreativitas siswa dapat dikembangkan dengan cara guru menekankan kepada siswa untuk berpikir divergen.Sebagaimana yang dijelaskan oleh Nasution (2013:108) yang menjelaskan bahwa kreativitas siswa dapat muncul dan berkembang melalui kemampuan berpikir yang divergen yaitu dapat menyelesaikan permasalahan matematika melalui cara-cara non prosedural dengan melihat sisi lain dari permasalahan matematika tersebut.Pendapat diatas menjelaskan bahwa siswa yang berpikir divergen dapat memberikan ide dan gagasan dalam menyelesaikan suatu permasalahan matematika hingga permasalahan tersebut dapat di selesaikan dengan berbagai cara dan bahkan lebih dari satu solusi penyelesaian. Handoko (2013:189) menyatakan bahwa, matematika dapat difungsikan untuk mengembangkan kemampuan berpikir kreatif yang sistematis, logis, kreatif, disiplin dan kerjasama yang efektif dalam kehidupan yang modern dan kompetitif. Menurut pendapat di atas, kemampuan berpikir kreatif dapat dikembangkan dengan pembelajaran matematika karena matematika melatih membangun pola berpikir logis, analisis, dan sistematis. Hal ini berdampak pada pembentukan kemampuan individual yang siap menghadapi kehidupan modern dan penuh kompetisi.Berdasarkan beberapa definisi kreatif dari beberapa ahli di atas maka dapat disimpulkan bahwa kreatif adalah suatu penemuan terbaru yang didapat dari gagasan dan ide-ide yang dapat dikembangkan dengan mengkombinasikan gagasan dan ide-ide yang telah ada sehingga menghasilkan sesuatu yang baru

Kata kreatif sering berpadanan kata dengan berpikir, dimana kedua kata memiliki arti atau makna masing-masing. Namun ketika kedua kata tersebut dipadukan, yaitu berpikir kreatif maka akan memiliki arti yang saling mempengaruhi satu sama lainnya. Berpikir kreatif memiliki arti sebagai kegiatan untuk menghasilkan suatu ide, gagasan, pemecahan masalah, mampu menemukan pola tertentu yaitu saling menghubungkan satu sama hal dengan hal lainnya untuk menemukan makna.Pengertian berpikir kreatif menurut Johnson (2013:289) adalah mencari kesempatan untuk mengubah sesuatu menjadi lebih baik. Pemikir kreatif melihat diri mereka tinggal di sebuah konteks, konteks keluarga, sekolah, kota, atau ekosistem, dan mereka mencoba untuk meperbaiki konteks ini. Pendapat di atas dapat di simpulkan bahwa dengan berpikir kreatif, seseorang dapat menghasilkan suatu ide atau gagasan yang dapat merubah produk lama menjadi produk baru.Senada dengan Johnson, menurut Haerudin (2011:289) berpikir kreatif adalah suatu proses berpikir untuk menemukan sesuatu yang bisa mengubah atau memperbaiki kondisi apapun sehingga menjadi lebih baik. Pendapat di atas dapat dijelaskan bahwa manfaat dari berpikir kreatif adalah mengubah kondisi seseorang dari yang kurang baik ke arah yang lebih baik. Contohnya adalah seorang pedagang yang mengubah produk dagangnya menjadi berbeda dari yang lain dan menarik sehingga konsumen tertarik pada produknya. Maka berpikir kreatif adalah sebagai kemampuan untuk menghasilkan atau mengembangkan sesuatu yang baru, yaitu sesuatu yang berbeda dari ide-ide yang dihasilkan kebanyakan orang dan berpikir kreatif memiliki kemampuan dan hasil berpikir yang berbeda satu sama lain. Berpikir kreatif merupakan salah satu jenis berpikir (thinking) yang mengarahkan diperolehnya wawasan (insight) baru, pendekatan baru, perspektif baru, atau cara baru dalam memahami sesuatu. Hal serupa mengenai pengertian berpikir kreatif diungkapkan oleh Munandar (2012:19) berpikir 
kreatif berarti mengembangkan talenta yang dimiliki, belajar menggunakan kemampuan diri sendiri secara optimal, menjajaki gagasan baru, tempat-tempat baru, aktivitasaktivitas baru, mengembangkan kepekaan terhadap masalah lingkungan, masalah orang lain, dan masalah kemanusiaan.

Berpikir kreatif memberikan manfaat pada kehidupan seseorang seperti menambah pengetahuan baru dan menciptakan solusi untuk memecahkan masalah, sebagaimana yang diutarakan oleh Johnson (2013:28) manfaat berpikir kreatif sangat luas, tak terbatas dan tidak dapat dibatasi sehingga mampu menemukan hal-hal yang sama sekali baru atau ide/konsep yang terbarukan.Seseorang yang selalau berpikir kreatif akan berdampak pada pribadi orang tersebut dalam merencanakan dan memutuskan suatu tindakan dan pribadi yang kreatif biasanya lebih terorganisasi dalam tindakan. Rencana inovatif serta produk orisinil mereka telah dipikirkan dengan matang terlebih dahulu dengan mempertimbangkan masalah yang mungkin timbul dan implikasinya, maka dengan berpikir kreatif, suatu rencana dapat dijalankan dengan baik dan hati-hati mulai dari tahap perencanaan sampai pelaksanaannya. Berdasarkan beberapa pengertian berpikir kreatif menurut para ahli di atas dapat disimpulkan bahwa berpikir kreatif adalah kemampuan untuk menciptakan sesuatu yang baru, sesuatu yang berbeda dari yang lain, menciptakan solusi untuk memecahkan masalah, dan membuat rencana inovatif seta orisinil yang dalam pelaksanaannya dilakukan dengan matang dengan dipertimbangkan masalah yang mungkin timbul dan cara mengatasinya.

Matematika berasal dari bahasa Yunani, yaitu Manthanein yang artinya 'belajar' atau Mathema yang artinya 'hal yang dipelajari. Matematika merupakan ilmu yang digunakan dalam setiap bidang ilmu pengetahuan baik Ilmu Pengetahuan Alam maupun Ilmu Pengetahuan Sosial. Di zaman modern ini penerapan ilmu matematika sangat berguna dalam perkembangan teknologi. Misalnya penggunaan algoritma dalam pemrograman robot dan dalam membuat berbagai macam aplikasi yang dapat dipakai di komputer ataupun handphone.Menurut Lestari (2012:173) bahwa matematika adalah ilmu pengetahuan mengenai logika bentuk, susunan, sasaran, dan konsep-konsep yang terbagi menjadi beberapa cabang dalam setiap kajiannya bersifat logis, sistematis, dan konsisten. Maka matematika adalah suatu struktur atau susunan dari konsep-konsep, logika, dan dalil-dalil yang telah terbukti keshahihannya dan berlaku secara sistematis dan logis dalam setiap kajian ilmu. Menurut Wirda (2011:863) bahwa matematika mengalami perubahan dari semula hanya mengandung pengertian menghitung, mengukur, dan mempelajari bentuk-bentuk secara sistematis seta gerakan objek-objek secara fisik. Maka matematika mengalami peningkatan seiring dengan banyaknya permasalahan yang berkembang. Perkembangan yang pesat menjadikan matematika menjadi penting untuk semua bidang ilmu lainnya sehingga semua ilmu memerlukan matematikawan untuk mempelajarinya.

Menurut Supardi (2013:82) bahwa matematika adalah ilmu pengetahuan yang diperoleh dengan bernalar yang menekankan aktivitas dalam dunia rasio dari seluruh segi kehidupan manusia, mulai yang sederhana sampai pada yang paling kompleks. Pendapat di atas dapat di simpulkan bahwa perilaku berpikir matematis dilakukan dari objek yang paling sederhana ke objek yang lebih kompleks.Matematis berasal dari kata metematika yang memiliki arti bersifat matematika, bersangkutan dengan matematika, sangat pasti, dan tepat. Para ahli tidak mendefinisikan kata matematis secara khusus dan kata matematis dapat memiliki makna ketika disandingkan dengan kata lain, tetapi matematis berhubungan dengan definisi matematika. Sebagai contoh berpikir kreatif dalam pembelajaran matematika lebih tepat dikatakan berpikir kreatif matematis. Hal ini karena berpikir kreatif disini mengarah kepada kemampuan matematika, prosedural dalam memecahkan masalah, dan segala sesuatu tentang matematika. Sebagaimana yang 
dikatakatan oleh Kartini (2011:145) bahwa kreativitas dalam matematika lebih ditekankan pada prosesnya, yakni proses berpikir kreatif. Oleh karena itu kreativitas dalam matematika lebih tepat diistilahkan sebagai berpikir kreatif matematis.

Contoh lainnya yaitu kemampuan berpikir kritis, jika di kaitkan dengan pembelajaran matematika maka lebih tepatnya kemampuan berpikir kritis matematis. Sebagaimana yang dikatakan oleh Kurniasih (2013:82) bahwa berpikir kritis dalam matematika akan menjadikan pebelajar mampu mengorganisai dan menggabungkan berpikir matematis melalui komunikasi, mengkomunikasikan berpikir matematisnya secar koheren dan jelas kepada pebelajar yang lain, guru, dan orang lain, menganalisis dan mengevaluasi berpikir matematis dan strategi, menggunakan matematika untuk mengekspresikan ide-ide matematika dengan tepat.

Kehidupan setiap manusia tidak lepas dari kegiatan berpikir baik yang bermakna maupun tidak, berpikir untuk menyelesaikan masalah, berpikir untuk kehidupan di esok hari, berpikir menjaga dirinya dari kecelakaan dan kejahatan, dan lainlainnya. Segala bentuk kegiatan tersebut dapat dikatakan kemampuan berpikir dan kemampuan berpikir setiap orang berbeda-beda baik dari segi usia, jenjang pendidikan, ataupun kondisi. Jika kita fokuskan kemampuan berpikir pada dunia pendidikan maka kita akan mendapatkan seorang siswa yang menghafal, menjawab soal, melakukan eksperimen, melakukan pengamatan, membuat alat peraga, dan lain-lain. Kemampuan berpikir kreatif menurut Nasution (2013:107) adalah kemampuan yang harus dimiliki oleh siswa yang apabila kebiasaan berpikir kreatif berlangsung secara berlanjut maka secara akumulatif akan tumbuh suatu disposisi (disposition) terhadap berpikir kreatif. Pendapat di atas menjelaskan bahwa kebiasaan berpikir kreatif akan berpengaruh pada disposisi/karakter siswa menjadi kreatif. Adapun kreativitas dalam matematika lebih ditekankan pada prosesnya, yakni proses berpikir kreatif. Oleh karena itu kreativitas dalam matematika lebih tepat diistilahkan sebagai berpikir kreatif matematis,maka kemampuan berpikir kreatif dalam matematika mengarah pada kemampuan berpikir kreatif matematis.

Cara yang dapat dilakukan untuk meningkatkan kemampuan berpikir kreatif matematis adalah dengan menciptakan kondisi pembelajaran yang kondusif. Hal ini sebagaimana yang diutarakan oleh Fisher dalam Kartini (2011:146) untuk dapat berpikir kreatif, perlu adanya stimulus untuk memicu siswa berpikir. Stimulus dapat berupa pemberian masalah yang menantang di awal pembelajaran. Menurut pendapat di atas dapat disimpulkan bahwa dengan diberikannya stimulus/ rangsangan pemberian masalah dalam belajar dapat menumbuhkan dan meningkatkan kemampuan berpikir kreatif matematis.

Mengetahui kemampuan berpikir kreatif matematis siswa diperlukan adanya kajian yang mencakup kemampuan berpikir kreatif. Menurut Hidayat (2011:274) berpikir kreatif matematis adalah kemampuan yang meliputi keaslian, kelancaran, kelenturan, dan keterperincian respon siswa dalam menggunakan konsep-konsep matematika. Senada dengan Hidayat, menurut Munandar (2012:192) terdapat empat kajian kreatif dalam kajian matematika yaitu kelancaran (fluency) menjawab, keluwesan jawaban (fleksibilitas), orisinalitas dalam berpikir matematis, dan kemampuan berpikir terperinci (elaborasi).

Dari empat kajian kreatif mengenai kemampuan berpikir kreatif matematis di atas dapat dijelaskan sebagai berikut:

1) Kelancaran menjawab adalah kemampuan siswa di dalam menjawab masalah matematika secara tepat dan tidak bertele-tele.

2) Keluwesan menjawab adalah kemampuan menjawab masalah matematika melalui cara yang tidak baku. 
3) Keaslian adalah kemampuan menjawab matematika dengan menggunakan bahasa, cara, atau idenya sendiri.

4) Elaborasi adalah kemampuan memperluas jawaban masalah, memunculkan masalah baru, atau gagasan baru.

(Setiyani, 2013: 353-354)

Kesimpulan dari penjelasan di atas dapat kita buat indikator kemampuan berpikir kreatif yang digunakan dalam penelitian ini adalah sebagai berikut:

1) Berpikir lancar (Fluency) Indikator: mampu mencetuskan banyak gagasan, jawaban, atau penyelesaian.Perilaku siswa:

a) Lancar mengungkapkan gagasan-gagasannya.

b) Menjawab dengan sejumlah jawaban jika ada pertanyaan.

c) Mempunyai banyak gagasan mengenai suatu masalah

2) Berpikir luwes (Flexibility)

Indikator: mampu menghasilkan gagasan, jawaban, atau pertanyaan yang bervariasi. Perilaku siswa:

a) Jika diberikan masalah biasanya memikirkan bermacam-macam cara untuk menyelesaikannya.

b) Memberikan macam-macam penafsiran terhadap suatu masalah.

3) Berpikir orisinal (Originality)

Indikator: mampu memberikan gagasan yang baru dalam menyelesaikan masalah atau memberikan jawaban yang lain dari yang sudah biasa dalam menjawab suatu pernyataan.

Perilaku siswa:

a) Mampu membuat ungkapan yang baru dan unik

b) Memilih cara berpikir lain dari pada yang lain.

4) Berpikir elaborasi (Elaboration)

Indikator: mampu memperkaya dan mengembangkan suatu gagasan atau produk.Perilaku siswa:

a) Mencari arti yang lebih mendalam terhadap jawaban atau pemecahan masalah dengan melakukan langkah-langkah yang terperinci.

b) Mengembangkan dan memperkaya gagasan yang telah ada.

(Haerudin, 2011: 289-290)

Berdasarkan beberapa definisi kemampuan berpikir kreatif dari para ahli maka dapat disimpulkan bahwa kemampuan berpikir kreatif matematis adalah kemampuan untuk menyelesaikan masalah dengan mudah, sederhana, dan fleksibel yang ada hubungannya dengan matematika. Kemampuan berpikir kreatif matematis sangat diperlukan untuk melatih kemampuan berpikir logis, analitis, sistematis, kritis, dan kreatif, serta memiliki kemampuan bekerja sama.

Model pembelajaran dapat diartikan sebagai tampilan grafis, prosedur kerja yang teratur atau sistematis, serta mengandung pikiran yang bersifat uraian atau penjelasan. Uraian atau penjelasan menujukkan bahwa suatu model pembelajaran menyajikan bagaimana suatu pembelajaran dibangun atas dasar teori-teori seperti belajar, pembelajaran, psikologi, komunikasi, sistem, dan sebagainya. Menurut Arends dalam Suprijono (2013: 46) bahwa model pembelajaran mengacu pada pendekatan yang akan digunakan, termasuk di dalamnya tujuan-tujuan pembelajaran, tahap-tahap dalam kegiatan pembelajaran, lingkungan pembelajaran, dan pengelolaan kelas. Penjelasan di atas dapat disimpulkan bahwa model pembelajaran memiliki peranan penting sebagai kerangka konseptual yang menggambarkan prosedur yang sistematis dalam mengorganisasikan pengalaman belajar untuk mencapai tujuan belajar.Pendapat lain 
mengenai model pembelajaran menurut Joyce dalam Ngalimun (2013:7) bahwa model pembelajaran adalah suatu perencanaan atau suatu pola yang digunakan sebagai pedoman dalam merencanakan pembelajaran di kelas atau pembelajaran dalam tutorial dan untuk menentukan perangkat-perangkat pembelajaran termasuk di dalamnya buku-buku, film, komputer, kurikulum, dan lain-lain.

Pendapat di atas dapat disimpulkan bahwa model pembelajaran sebagai suatu kerangka dalam menentukan komponen-komponen penunjang belajar.Senada dengan Joyce mengenai definisi model pembelajaran, Munandar (2012:162) mengemukakan bahwa model pembelajaran dapat digunakan untuk menetukan materi atau konten pembelajaran dan metode-metode untuk penyampaian materi tersebut, dalam arti bahwa model memberikan kerangka untuk menentukan pilihan. Pendapat di atas dapat disimpulkan bahwa model pembelajaran menjadi penentu dalam keberhasilan pelaksanaan kegiatan belajar sehingga guru dituntut dapat memilih model pembelajaran yang tepat.Menurut Kasmad dan Pratomo (2012:7-8) banyak model pembelajaran baik eksak maupun non eksak. Dasar penggunaan model pembelajaran biasanya tergantung pada tujuan pembelajaraan, karakter pelajaran, media relevan dengan tujuan. Pertimbangan ini terletak pada kemampuan dan pengalaman guru. Pendapat di atas dapat disimpulkan bahwa peranan guru sangat penting dalam menentukan model pembelajaran yang akan diterapkan dikelas karena dapat mempengaruhi hasil belajar siswa.Berdasarkan beberapa pengertian model pembelajaran menurut para ahli maka model pembelajaran adalah pedoman untuk merancang aktivitas siswa dalam belajar sehingga dapat membantu siswa dalam mendapatkan informasi, ide, keterampilan, cara berpikir, dan mengekspresikan ide.

\section{Model Pembelajaran Missouri Mathematics Project (MMP)}

Dalam suatu proses pembelajaran terdapat berbagai komponen pembelajaran yang harus dikembangkan dalam upaya mendukung tercapainya tujuan pembelajaran dan keberhasilan siswa dalam tujuan pembelajaran dan keberhasilan siswa dalam belajar. Komponen-komponen tersebut diantaranya guru, siswa, model pembelajaran, metode pembelajaran, serta sumber dan media pembelajaran. Sebagai salah satu komponen pembelajaran, pemilihan model pembelajaran akan sangat menunjang pencapaian tujuan pembelajaran. Saat ini terdapat berbagai model pembelajaran yang dapat diterapkan dalam pembelajaran matematika. Salah satu diantaranya adalah model pembelajaran Missouri Mathematics Project (MMP).

Model pembelajaran ini mengungkapkan intervensi guru terfokus kepada bagaimana cara guru mengajar agar terjadi pembelajaran aktif melalui review harian, pengembangan, mengatur latihan terkontrol, melakukan evaluasi, dan instruksi seperti seatwork dan pekerjaan rumah. Sebagaimana yang diutarakan oleh Agoestanto dan Savitri (2013:72) karakteristik dari model pembeajaran Missouri Mathematics Project (MMP) ini adalah latihan soal. Latihan-latihan soal ini dimaksudkan untuk meningkatkan keterampilan dalam memecahkan masalah siswa. latihan-latihan soal ini merupakan suatu tugas yang meminta siswa untuk menghasilkan sesuatu (konsep baru) dari dirinya (siswa) sendiri. Senada dengan Agoestanto dan Savitri menurut Gitaniasari dalam Hanifa (2013:3) model Missouri Mathematics Project (MMP) merupakan suatu program yang didesain untuk membantu guru dalam hal efektivitas penggunaan latihan-latihan agar siswa mencapai peningkatan yang luar biasa. Pendapat di atas dapat disimpulkan bahwa dengan diterapkannya model Missouri Mathematics Project (MMP) diharapkan dapat meningkatkan belajar siswa.

Model pembelajaran Missouri Mathematics Project (MMP) banyak memiliki kelebihan diantaranya, siswa diberikan banyak latihan-latihan soal sehingga terampil 
dalam mengerjakan berbagai macam soal. Latihan-latihan soal tersebut diantaranya adalah lembar kerja siswa, latihan kelompok, dan tugas rumah/PR. Selain itu banyak materi bisa tersampaikan kepada siswa karena tidak memakan banyak waktu. Artinya, penggunaan waktu relatif lebih ketat.Selain itu, kelebihan model pembelajaran Missouri Mathematics Project (MMP) menurut Jannah, dkk. (2013:63)model pembelajaran Missouri Mathematics Project (MMP) juga melatih kerjasama antar siswa pada langkah kerja kooperatif, mengerjakan lembar kerja secara berkelompok akan membuat siswa saling membantu kesulitan masing-masing dan saling bertukar pikiran.Pendapat di atas menjelaskan, misalkan ketika ada siswa yang malu bertanya kepada guru jika ada kesulitan dalam memahami materi yang sedang dipelajari maka langkah kerja kooperatif ini sangat membantu mereka karena siswa cenderung terbuka kepada teman sejawatnya sehingga pada langkah ini akan membantu siswa dalam memahami materi dan mengakibatkan sikap positif siswa terhadap matematika juga meningkat.

Langkah-Langkah Penerapan Model Pembelajaran Missouri Mathematics Project (MMP) dapat dijelaskan secara rinci, yaitu sebagai berikut:

1) Review

Pada tahap ini, guru dan siswa meninjau ulang apa yang telah tercakup pada pelajaran yang lalu yang ditinjau adalah PR, mencongkak, dan membuat perkiraan.

2) Pengembangan

Pada tahap ini, guru menyajikan ide baru dan perluasan konsep matematika terdahulu. Siswa diberi tahu tujuan pelajaran yang memiliki "antisipasi" tentang sasaran pelajaran. Penjelasan dan diskusi interaktif antara guru-siswa harus disajikan termasuk demonstrasi kongkrit yang sifatnya piktorial atau simbolik. Pengembangan akan lebih bijaksana bila dikombinasikan dengan kontrol latihan untuk meyakinkan bahwa siswa mengikuti penyajian materi baru itu.

3) Kerja Kooperatif

Pada tahap ini, siswa diminta merespon satu rangkaian soal sambil guru mengamati kalau kalau terjadi miskonsepsi. Pada latihan terkontrol ini respon setiap siswa sangat menguntungkan bagi guru dan siswa. Pengembangan dan latihan terkontrol dapat saling mengisi. Guru harus memasukkan rincian khusus tanggung jawab kelompok dan ganjaran individual berdasarkan pencapaian materi yang dipelajari. Siswa bekerja sendiri atau dalam kelompok belajar kooperatif.

4) Kerja Mandiri/ Seatwork

Pada tahap ini, digunakan latihan perluasan konsep yang disajikan guru pada tahap pengembangan.

5) Penugasan/ Homework

Pada tahap ini, diberikan pekerjaan rumah atau homework kepada siswa agar siswa juga belajar di rumah dan pekerjaan rumah harus memuat beberapa soal review.

(Jannah, dkk, 2013: 62-63)

Dari beberapa definisi di atas dapat disimpulkan bahwa model pembelajaran Missouri Mathematics Project (MMP) adalah model pembelajaran yang mengarahkan siswa pada latihan-latihan terkontrol, meliputi review, pengembangan, kerja kooperatif, kerja mandiri, dan PR, guna mendapatkan peningkatan belajar yang tinggi.

\section{PENUTUP Simpulan}

Berdasarkan pendapat dan teori di atas, maka pemberian model pembelajaran Missouri Mathematics Project (MMP) mempunyai pengaruh meningkatkan kemampuan berpikir kreatif matematis siswa. Berdasarkan hal tersebut hendaknya para guru selalu 
berupaya untuk merencanakan model pembelajaran yang tepat dan bervariasi dalam memberikan pelajaran kepada siswa khususnya pada pelajaran matematika.

Dalam pembuatan Rencana Pelaksanaan Pembelajaran (RPP) guru harus mengalokasikan waktu untuk membuat kelompok-kelompok belajar, waktu untuk berdiskusi, waktu untuk mengerjakan soal kelompok dan waktu untuk mengerjakan soal individu, dan mengalokasikan waktu untuk memberikan penghargaan kepada kelompok. Pemberian model pembelajaran Missouri Mathematics Project (MMP) ini tidak hanya didukung oleh guru, peserta didik dan lingkungan, tetapi perlu dukungan orang tua juga sebagai pembimbing peserta didik apabila ada penugasan dari sekolah yang mengharuskan ada bimbingan dari orang tua.

\section{Saran}

Berdasarkan penelitian yang telah penulis lakukan maka ada beberapa saran sebagai berikut:

1. Hendaknya guru diharapkan memberikan model pembelajaran yang tepat kepada siswa khususnya model pembelajaran Missouri Mathematics Project (MMP) sehingga dapat meningkatkan kemampuan berpikir kreatif matematis siswa.

2. Hendaknya guru mengarahkan siswa dalam merancang waktu pembelajaran dengan efektif dan efisien agar tiap langkah-langkah dalam model pembelajaran Missouri Mathematics Project (MMP) dapat berjalan dengan baik terutama pada pokok bahasan dengan materi yang padat sehingga setiap indikator pencapaian kompetensi dalam materi dapat tercapai.

3. Hendaknya siswa bisa lebih bertanggung jawab atas pembelajaran yang telah diterima.

4. Dengan adanya keterbatasan pada penelitian ini maka disarankan adanya penelitian lebih lanjut untuk mengetahui apakah pemberian model pembelajaran Missouri Mathematics Project (MMP) akan memberikan kemampuan berpikir kreatif matematis yang lebih baik untuk pokok bahasan seluruh mata pelajaran atau sampel yang dapat mewakili beberapa sekolah dengan kondisi yang berbeda untuk setiap jenjang pendidikan yang berbeda pula..

\section{DAFTAR PUSTAKA}

Agoestanto, Arief dan Soviana Nur Savitri. 2013. Keefektifan pembelajaran matematika mengacu pada missouri mathematics project terhadap kemampuan pemecahan masalah. Prosiding Seminar Nasional Matematika VII UNNES, 26 Oktober 2013: 71-77.

Darmadi, Hamid. 2010. Kemampuan Dasar Mengajar. Bandung: Alfabeta.

De Bono, Edward. 2007. Revolusi Berpikir Edward De Bono: Belajar Berpikir Canggih dan Kreatif Dalam Memecahkan Masalah dan Memantik Ide-Ide Baru/Edward De Bone. Diterjemahkan oleh: Ida Sitompul dan Fahmi Yamani. Bandung: Kaifa.

Haerudin. 2011. Penerapan Metode SAVI Dengan Pendekatan Induktif dan Peningkatan Berpikir Kreatif Matematis. Prosiding Seminar Nasional Pendidikan Matematika STKIP Siliwangi Bandung. Volume 1 tahun 2011: 287291.

Handoko, Hendri. 2013. Pembentukan Kemampuan Berpikir Kreatif Pada Pembelajaran Matematika Model SAVI Berbasis Discovery Strategy di Laboratorium Teezania. Prosiding Seminar Nasional Matematika VII UNNES, 26 Oktober 2013: 287-291

Hanifa, Qonif. 2013. Keefektifan Model Missouri Mathematics Project (MMP) dalam Mengukur Kemampuan Pemecahan Masalah Materi Persamaan dan 
Pertidaksamaan Linear Siswa Kelas X Akuntansi 1 SMK YPM 5 Sukodono Tahun Ajaran 2012-2013. Jurnal Penelitian. 1(1): 1-9.

Hidayat. 2011. Meningkatkan Kemampuan Berpikir Kreatif Matematik Siswa Sekolah Menengah Atas Melalui Pembelajaran Kooperatif Think-TalkWrite (TTW). Prosiding Seminar Nasional Pendidikan Matematika STKIP Siliwangi Bandung. Volume 1 tahun 2011: 272-279.

Jannah, dkk. 2013. Penerapan Model Missouri Mathematic Project (MMP) untuk Meningkatkan Pemahaman dan Sikap Positif Siswa Pada Materi Fungsi. Jurnal Pendidikan Matematika Solusi. 1(1): 61-66.

Johnson, Johnson. 2013. The Way of Thinking: Tingkatkan Cara Berpikir agar Lebih Kreatif, Rasional, dan Kritis. Jakarta: PT Elex Media Komputindo.

Kartini. 2011. Peningkatan Kemampuan Berpikir Kreatif Matematis Siswa SMA Melalui Pembelajaran Inkuiri Model Alberta. Prosiding Seminar Nasional Pendidikan Matematika STKIP Siliwangi Bandung. Volume 1 tahun 2011: 145153.

Kasmad, Mamad dan Pratomo, Suko. 2012. Model-Model Pembelajaran Berbasis PAIKEM. Tangerang: Pustaka Mandiri.

Kurniasih, Ary Woro. 2013. Kemampuan Berpikir Kritis Matematis Dalam Mengembangkan Keterampilan Mengajar Mahasiswa Calon Guru. Prosiding Seminar Nasional Matematika VII UNNES, 26 Oktober 2013: 79-88.

Lestari, Witri. 2012. Efektifitas Strategi Pembelajaran dan Motivasi Belajar terhadap Hasil belajar Matematika. Jurnal Formatif, 2(3): 170-181.

Malaka, Sandy. 2011. 99 Tips Cerdas dan Efektif Berpikir Positif dan Berjiwa Besar. Yogyakarta: Araska.

Munandar, Utami. 2012. Pengembangan Kreativitas Anak Berbakat. Jakarta: Rineka Cipta.

Nasution, Eline Yanty Putri. 2013. Meningkatkan Kemampuan dan Disposisi Berpikir Kreatif Siswa melalui Pendekatan Open-Ended. Prosiding Seminar Nasional Matematika VII UNNES, 26 Oktober 2013: 107-116.

Ngalimun. 2013. Strategi dan Model Pembelajaran. Yogyakarta: Aswaja Pressindo.

Purwanto, Ngalim. 2002. Psikogi Pendidikan. Bandung: PT. Remaja Rusdakarya.

Setiyani. 2013. Mengembangkan Kemampuan Berpikir Kreatif Siswa Melalui Pembelajaran Topik Bangun Ruang Sisi Datar. Prosiding Seminar Nasional Matematika VII UNNES, 26 Oktober 2013: 351-360.

Supardi. 2013. Hasil Belajar Matematika Siswa Ditinjau dari Interaksi Tes Formatif Uraian dan Kecerdasan Emosional. Jurnal Formatif, 2(3): 78-96.

Suprijono, Agus. 2013. Cooperative Learning: Teori dan Aplikasi PAIKEM. Yogyakarta: Pustaka Pelajar.

Wirda, Yendri. 2011. Studi Efektivitas Cooperative Learning (CL) dalam Pembelajaran Sains dan Matematika (Suatu Meta Analisis terhadap Hasilhasil Penelitian Pendidikan). Jurnal LITJAK. 12(12): 858-878. 